\title{
APPENDIX XIII
}

\section{Letters written by Dipanagara from Batavia (1830) and Makassar (1837)}

A

The following two letters were probably written by Dipanagara from Batavia before his departure on 3 May 1830..$^{1}$ They were addressed to close members of his family and are the only letters known to exist which were written in his hand and not by a scribe. The unusual carelessness of the handwriting, the unnecessary doubling of the letters (aksara) in some places, and the occasional grammatical errors, all confirms Dipanagara's later admission to Lieutenant J.H. Knoerle that 'he wrote Javanese very defectively' (Knoerle to Van den Bosch, 9 July 1830 in De Oosterling, volume 2 (1835), page 172). The originals are on Dutch government paper and were found by the Dutch scholar, J.J. de Hollander, in a file of correspondence between Javanese bupati, post-commanders and Dutch authorities relating to the Java War (1825-1830) in the archive of the Royal Military Academy at Breda. De Hollander published them in Javanese script with Dutch translations in Bijdragen tot de Taal-, Landen Volkenkunde 25:192-6. He retained the original spelling and included copious corrections in his notes which have not been reproduced here. This is the first time the letters have been published in Romanised script with English translations.

(i) Dipanagara to his eldest son, Pangéran Dipanagara the Younger, n.d.

Sawusé salam dunganingsun Kulup Dipanegara marang sira apa déné marang adhinira Basah Mertanegara Basah Gadakusuma apa déné

1 The letters may have been given to Captain Johan Jacob Roeps to take back to south-central Java when Dipanagara took leave of him on board the Corvette Pollux in Batavia harbour on 3 May 1830, Knoerle, 'Journal', 2. A passage in Dipanagara's autobiography suggests that he gave Roeps special instructions to keep an eye on his children at this time: BD (Manado) IV:320, XLIII (Maskumambang) 272-4. ingsun banget lega yektil sira mulih mring Mentaram. 273. pan dènbisa sirèku ngopèn-opènil mring kang kèri padal sabab bocah padha meksih/ tanggung pesthi kèh kurangnya. 274. ingkang pikir. Roeps' departure on leave for Holland in July 1830 may have meant that he was never able to deliver the letters, see Louw and De Klerck 1894-1909, II:283 note 2. 
adhinira kabèh aja padha mikir marang ingsun sawab ingsun wos dadi karemnaningsun bakal sun tutugaken olé ingsun lelana karu déné manahé Sibèng Jayakusuma banget temen welasingsun iku yèn pareng padha sarjuné dhaupna karu adhènira Basah Gadakusuma aja tanggung olèhira dowé sadulur apa déné olé ingsun duwé anak apa déné sira kabèh wus aja na kuwatir sawab wus sun titepaké marèng Gupermèn karo déné manahé pamanira Kapitan Rup iku bangeng pracayaningsun wekasingsun marang sira Dipanegara Mertanegara Gadakusuma yèn ana keng dadi kasusahan atènira becik pamanira Kapitan sira ajak karerembungan.

\section{English translation:}

After my greetings and prayers to you my son, Dipanagara, and also to your younger brothers Basah Mertanagara ${ }^{2}$ and Basah Gandakusuma ${ }^{3}$ and to all your younger brothers and sisters, do not concern yourselves about me because I am well content to continue my wanderings. Moreover, for your younger sister, little girl Jayakusuma, ${ }^{4}$ great indeed is my heart's concern. If they agree to it, marry her to your younger brother brother Basah Gandakusuma. Do not neglect to care for your siblings, my children, and do not be concerned, all of you, for I have entrusted you to the [Dutch] government. Furthermore, my heart has the fullest trust in your uncle Captain [Johan Jacob] Roeps [and] I order you Dipanagara, Mertanagara [and] Gandakusuma that if there is anything troubling your hearts, it is good that you ask advice from your uncle the Captain.

(ii) Dipanagara to his mother, Radèn Ayu Mangkarawati, n.d.

Sampuning sembah kula ingkang kathah-kathah katura ing sampéyan

2 Ali Basah Ngabulkamil Mertanagara (earlier Lurah Jayapermadi) was the eldest son of Radèn Adipati Danureja II (in office 1799-1811) by an unofficial wife, Mas Ayu Pulangyun. He followed Dipanagara throughout the war and by the end had become one of his most trusted advisers, especially after his marriage to one of Dipanagara's daughters, Appendix IV. He was later an influential figure at the Yogya court and was close to the Crown Prince, Pangéran Mangkubumi (later Hamengkubuwana VI, reigned 1855-1877). But this influence was tempered by general revulsion at his immoral behaviour, Dj.Br. 18, Valck, 'Geheime Memorie', 31-3-1840; Appendix IV, pt. 1 note 5.

3 Ali Basah Abdul Mahmud Gandakusuma (earlier Lurah Sukapja) was a younger brother of the above. He also became a trusted adviser and army commander of Dipanagara at the end of the Java War, but declined marriage with Dipanagara's widowed daughter, marrying instead the favourite sister of Hamengkubuwana V, Mandoyokusumo 1977:38 no. 8. He later became patih of Yogya with the title Radèn Adipati Danureja V (in office 1847-1879), after serving for long as senior administrator of the royal domains (bupati pamajegan-Dalem).

4 On Radèn Ayu Jayakusuma see Appendix IV. 
kula ngatar pirsa dhateng sampéyan lampah kula wilujeng ing samargimargi boten sanès kalih wonten Magelang mila kula ngatari pirsa dhateng sampéyan mugi sampun dadus kasusahan anggalih dhateng kula sawab sampun dados suka-pirenanipun manah kula piyambak kalih kula pasrah wayah-wayah sampéyan sedaya punapa déné awak kula piyambak rumaos ageng temen kalepatan kula dhateng sampéyan ing lair punapa déné ingkang batos mugi wontena sih pengapunte[n] sampéyan dhateng kula ingkang ageng punapa déné dhateng Kanjeng Rama inggih sami ugi lepat kula mila wayah-wayah sampéyan yèn dhangan sami ngaosna dhateng Kanjeng Rama niyata nyuwonaken apunte[n] dhateng kalepatan kula ingkang lair punapa déné ingkang batos.

\section{English translation}

After my many humble obeisances to you [mother], I offer you the news that my course has been fortunate throughout my whole journey, no different from what it was at Magelang. The reason I am informing you of this is that you should not be concerned about me because my heart is already fully satisfied, and I entrust to you all your grandchildren. Moreover, I myself feel how truly enormous are my faults towards you both outward and inward. May there be much forgiveness on your part towards me. Likewise towards His Highness, my father, ${ }^{5}$ [many] also are my faults. Thus, when they have the opportunity, your grandchildren must offer up to His Highness, my father, the religious intention of begging forgiveness for my faults both outward and inward.

$B$

The following letter was written by Dipanagara from Makassar on 14 December 1835 to Major-General Jan Baptist Cleerens (1785-1850), ${ }^{6}$ the Flemish officer (then a colonel) who had negotiated with him at Rèmakamal and Kecawang in northern Bagelèn, and at Menorèh in southern Kedhu in February 1830, and had persuaded him to go on to meet General H.M. de Kock in Magelang on 8 March 1830 where he was later arrested on 28 March 1830. This letter together with another which Dipanagara wrote in the following year to the guardians of Hamengkubuwana $\mathrm{V}$ about the marriage of one of his daughters caused considerable consternation in Dutch official circles. First, because of the royal style adopted in the letters in which Dipanagara referred to himself by some of the titles he had used during the Java War, such as 'Sultan Èrucakra' (The Just King), 'Kabiril Mukminin' (The First among the Believers), and 'Kalipah Rasulollah Jawa' (The Caliph of the Prophet of God in Java), and because he

Sultan Hamengkubuwana III (1812-1814) of Yogyakarta.

For details of Cleerens' army career, see Louw and De Klerck 1894-1909, I:326 note 1. 
addressed Cleerens in Low Javanese (ngoko) and as 'younger brother' (rayi, adhi). Secondly, Dutch officials were concerned that Dipanagara both knew about Cleerens's return to Java on 13 October 1835, a bare two months before this letter was written, and had the means of communicating secretly with Java, usually through sealed correspondence taken by skippers of Indonesian trading ships, in particular Makassarese praus. Finally, the letter seemed to draw Cleerens's attention to a promise which Dipanagara thought had been made to him guaranteeing his safe return to Bagelèn if the Magelang 'peace' negotiations were not to his liking. ${ }^{7}$ These concerns formed the background

7 Dipanagara's view of Cleerens' undertaking to him before his journey to Magelang can be seen quite clearly in his autobiography, BD (Manado) IV:299-301, XL (Megatruh) 170-9 mengkana ngandika aris/ Hèh Kurnèl apa rembagmu/ kalamun prayaga ikil iya lawan karsaningong. 171. sun turuti mengkana Kurnèl turipun/ ingkang kepanggih Déwajil raosing manah pukulun/ Paduka mapan prayogil ngrumiyinana mring Kedhu. 172. mupung Jéndral pan dèrèng dhateng puniku/ pan dugi kawula Déwajil datan ngantos Siyam tuhu/ Jéndral pesthi nunten praptil sabab kawula Sang Katong. 173. anusuli serat yèn Paduka éstu/ pan arsa panggih pribadil mila dugi nunten wangsul/ punika yèn saupamil karsa-Dalem boten dados. 174. Paduka Ji kawula aturi wangsull inggih mring Bagelèn malih/ sanadyan dados satuhul pan tangled sami Welandil kawula pan nemah Katong. 175. nging panuhun kawula mapan satuhul Panjenengan-Dalem ugil mapan sampun ngantos ikul kagepok mring lepatnèkil lan damel perkawis mangko. 176. amiwiti kalamun cidra Sinuhun/ pan mongsa wandéya panggih/ mring awak pribadènipun/ mengkana Sri Narapati/ sareng mirsa aturipun. 177. Kurnèl Klérès lawan Mayor Bokus ikul ingkang tya/s Nata pan gampil/ kadya wus karsa Hyang Agung/ nanging sumedhé mring tekdirl èsmu wirang Jeng Sang Katong. 178. lamun ngantos sumingkir dum-duman ikul iya wong anèng dunyèkil mengkana Ingkang Sinuhun/ mapan nulya ngandika ris/ hèh Kurnèl aturirèku. 179. sun turuti. 170. then softly spoke [the Sultan]:/ 'Eh, Colonel, what is your advice?/ If it is appropriate/ with my wishes 171. I will follow it.' Thus was the Colonel's speech/ '[If] it suits, Your Highness,/ my heart's feelings/ are that it would be desirable, Highness, /[for you] to go first to Kedhu. 172. Although the General [De Kock] has still not arrived there,/ my opinion, Highness,/ is that in truth before the fasting month,/ the General will certainly arrive/ for I have already. 173. sent a letter to reach him that Your Highness really wishes/ to meet him in person./ Thus I think he will soon return./ But if, for example,/ Your Highness's wishes are not accomplished 174. [then] Sultan, I invite you to return/ indeed to Bagelèn again./ Even if it really comes/ to resistance with the Dutch/ I will chance it Sultan. 175. But truly my request/ is that Your Highness also/ must not go so far as to be/ affected by [personal] faults/ and make an issue. Besides, 176. if Highness, treachery is initiated,/ those involved will not fail to have to do/ with me personally.'/ Now the Sultan,/ when he heard the speech 177. of Colonel Cleerens and Major Buschkens $\left({ }^{*}\right), /$ was easy at heart./ It was as if it was the wish of the Almighty/ that he should resign himself to his fate./ Openly ashamed would be the Sultan 178. if he went so far as to escape his lot/ as a man in this world./ Thus His Highness/ straightway spoke in a friendly fashion:/ 'Ah, Colonel, that speech of yours. 179. I will follow'.

${ }^{*}$ ) Major Hendrik Frederik Buschkens (1795-1860), a Dutch officer who was second-in-command to Colonel Cleerens at the time of the negotiations with Dipanagara in Bagelèn and Kèdhu in February 1830. For a further discussion of Dipanagara's assumptions about the undertakings he thought Cleerens had given him, see Louw and De Klerck 1894-1909, V:564-5. Cleerens's own version of the negotiations can be found in the dispatches which he wrote to his superior, Colonel F.D. Cochius; in Magelang from 16 February until 28 February 1830 which are in dK 209. These show that he treated Dipanagara, openly at least, with respect, addressing him by his title of 'Sultan' (something which De Kock later refused to do in Magelang), and speaking to him directly in Malay, dK 209, Colonel J.B. Cleerens (Menorèh) to Colonel F.D. Cochius (Magelang), 25-2-1830, Louw and De Klerck 1894-1909, V:544, 564-6. 
to the secret decision of the Governor-General in Council (AN Besluit van den Gouverneur-Generaal in rade, 15-3-1837 no. 57, geheim) which ordered that a large part of Dipanagara's entourage should be separated from him and sent to Ambon (in fact they were sent to Kyai Maja's settlement in Tondano via Ambon in June 1839, see Appendix XII); that Dipanagara should be guarded more closely in Makassar, his contacts limited to his immediate family and servants; and that all his mail should be opened. A further recommendation that the prince's monthly allowance should be substantially reduced was apparently not complied with by the governor of Makassar, see Appendix XII note 2.

The letter, which was probably dictated by Dipanagara to a scribe, was written on Dutch government paper in black ink with thick flowing pen strokes probably made with an arèn palm pen. Unlike his later letter to the guardians of Hamengkubuwana $\mathrm{V}$ and most of his other writings in Makassar it is in Javanese not pégon script. The yellow silk envelope (again a symbol of Dipanagara's royal pretensions) was addressed in a different hand with a thin quill pen. Both the envelope and original letter are now on display in the Arsip Nasional (National Archives) in Jakarta. A photograph of the latter together with a faulty Javanese transliteration and Indonesian translation have been published in Sagimun 1965:350-3.

\author{
Ngalamat serat dhumatenga Ingkang \\ Rayi Jinderal-Mayor Kalères,
}

\footnotetext{
Cleerens also seems to have assured the prince that he was personally responsible for his interests, although there is nothing in his dispatches to indicate that he gave him any specific undertaking about ensuring his return to Bagelèn should the Magelang 'peace' conference fail. Privately, he took a critical view of Dipanagara describing him as 'either a very stupid or a very hypocritical person' and belittling his understanding of Islam, see dK 209, Colonel J.B. Cleerens (Menorèh) to F.D. Cochius (Magelang), 26-2-1830. At the same time, he pressed Cochius to send sufficient reinforcements to enable him to carry out a coup de main against the prince and secure his arrest during the negotiations. In order to justify such conduct, Cleerens was constantly on the look out for evidence of 'treachery' on Dipanagara's part: for example, he often drew Cochius's attention to the prince's supposed failure to keep a promise not to increase his following by accepting new recruits from Bagelèn, see dK 209, Colonel J.B. Cleerens (Menorèh) to F.D. Cochius (Magelang), 27-2-1830. Of these private views and plans, Dipanagara seems to have been unaware. Even after his capture at Magelang, he continued to refer to Cleerens' supposed undertaking, see the report of Captain J.J. Roeps's conversation with Dipanagara at Ungaran on 28 March 1830 cited in 'Aanteekeningen gehouden door den Majoor Adjudant de Stuers bij het overbrengen van den gearresteerden Hoofdmuiteling Prins Diepo Negoro van Magelang naar Batavia', 9-4-1830, in Louw and De Klerck 1894-1909, V:741; and further Chapter XII.
} 
Ingkang pratadha Sinuwon Kajeng Sultan Ngabdulkamid Garucakra Kabiril Mukminin Kalipah Rasulollah Jawa, dhumatenga Ingkang Rayi Jinderal-Mayor Kalères, sawisé tabéningsun kang akèh-akèh Adhi Jinderal-Mayor Kalères marang sira, marmané ingsun akirim tulis sabab saking déné bangeté petengé penggalihingsun, awit Magelang saperana-saperené adhi nura nana kang sun galih-galih nanging paturanira marang ingsun, sabab sabarang paturanira akèh kang manujuni kalawan kang sabarang kang dadi karsaningsun, déné paturanira kang manujuni lan sabarang kang dadi karsaningsun iku anggèré ingsun aja nganti kagepok marang kaluputan baé, marmané adhi dadi banget temen cuwané galih ingsun sabab durong nganti tutug goningsun tatepungan lawan sira, wekasan ingsun dadi nemu susah banget kaya mengkéné sabarang lara $\mathrm{ku}[\mathrm{m}]$ pul ana ing galihingsun kabèh, kaya wong wus tan karuhan arané bareng ingsun mireng kabar terang lamun sira adhi ulèh pitulongé Gusti Alah Tangala bisa bali marang Jawa manèh, kaliwat padhangé galihingsun Adhi Jinderal-Mayor Kalères mongsa bodhoa pamikirira marang ingsun, tinulis Mekasar dina Isnèn tanggal ping telolikur sasi Ruwah taun Alip.

\section{English translation}

The declaration of His Highness Sultan Ngabdulkamid Èrucakra Kabiril Mukminin Kalipah Rasulullah of Java to his younger brother MajorGeneral Cleerens. After my many greetings to you younger brother Major-General Cleerens, the reason I am sending this letter is because of my heart's great gloom. From Magelang until now, younger brother, I have thought over nothing except your statements to me, because there was much in your statements which were in accord with my wishes. The [particular] statement of yours which was in harmony with my desires, dear [sir], was that I should not go so far as to be affected by [personal] faults. For this reason, younger brother, great indeed was my heart's disappointment that my acquaintance with you was not fulfilled. In the end, I met with this great sadness [when] all sorts of grief gathered in my heart. [But] I was like a senseless man, so I should say, when I heard the certain news that you, younger brother, had, with the help of the Almighty, been able to return to Java again. Exceeding was my heart's joy, younger brother Major-General Cleerens, [and now] it is up to you what your thoughts are for me.

Written in Makassar on Monday the twenty-third of the month Ruwah in the year Alip [AJ 1763] (14 December 1835). 